\title{
UNIVERSITYOF
}

FORWARD

THINKING

WESTMINSTER用

WestminsterResearch

http://www.westminster.ac.uk/westminsterresearch

Learning atmospheres: Re-imagining management education through the dérive

Michels, C., Hindley, C., Knowles, D. and Ruth, D.

This is a copy of the accepted author manuscript of the following article: Michels, C., Hindley, C., Knowles, D. and Ruth, D. (2020) Learning atmospheres: Re-imagining management education through the dérive, Management Learning. Advanced online publication. doi: $10.1177 / 1350507620906673$. The final definitive version is available from the publisher Sage at:

https://dx.doi.org/10.1177/1350507620906673

(C) The Author(s) 2020

The WestminsterResearch online digital archive at the University of Westminster aims to make the research output of the University available to a wider audience. Copyright and Moral Rights remain with the authors and/or copyright owners.

Whilst further distribution of specific materials from within this archive is forbidden, you may freely distribute the URL of WestminsterResearch: ((http://westminsterresearch.wmin.ac.uk/)).

In case of abuse or copyright appearing without permission e-mail repository@westminster.ac.uk 


\section{Learning Atmospheres: Re-imagining Management Education through the Dérive}

This paper responds to the recent calls for rethinking management education, particularly to those that emphasise space, affect and atmosphere and makes the case for the practice of dérive as a way of infusing management education with experiential, experimental and reflexive learning processes. The authors draw on ideas and practices of the art movement Situationist International who proposed the dérive, informed by the concept of psychogeography as a way of exploring and reimagining the atmospheres of everyday life. The paper is illustrated by the authors' teaching experiences in this area (or space as one might say). The authors argue that the dérive in management education may foster future managers' imaginative skills and inspire an imaginative self-reflection of the business school and its spatial organization. The paper concludes that in re-enacting their experience of educational space, participants may learn about, reflect on, and develop their affective capacities for becoming part of organizational processes, both as students of the business school and as future managers.

Key words: business school, dérive, educational space, imagination, learning atmosphere, psychogeography

\section{Introduction}

At a time when 'the dominant mode of thinking about the university [is] characteristically connected with the ideas of the "entrepreneurial university" (Barnett, 2013: 16), the university's future depends on its 'capacity continually to re-imagine itself' (p. iii) and management education in particular needs to explore 'new voices, themes and methods in teaching and researching' (Gherardi, 2016: 270). Contributing to the still relatively novel field in management education of walking methods (O'Neill and Roberts, 2020), we explore here the more specific idea of an open-ended walk as a drifting, as a means of making the familiar strange and at the same time a reflexive exercise that is as sensuous as possible. We draw inspiration from the art practice known as dérive which helps us understand how 
experiential, experimental and reflexive learning can be enacted in management education. The dérive was developed by the art movement Situationist International in the 1960s, defined as an interventionist practice, in which 'one or more persons during a certain period drop their relations, their work and leisure activities, and all their other usual motives for movement and action, and let themselves be drawn by the attractions of the terrain and the encounters they find there' (Debord, 2006a: 62). In other words, participants move through a locality paying attention to its atmosphere and imagine non-habitual ways of inhabiting these places. We argue that the Situationist practice can inform the education of future managers by a) providing a sensuous approach to the analysis of organizational atmospheres, b) exploring the creative and imaginative capacities that can be found in the enactment of spatial experiences, and c) fostering an awareness of the hidden potentialities of organizing. Since management is enacted in and through organizational spaces (Beyes and Steyaert, 2012), it seems reasonable to sensitise prospective managers to the ways in which their bodies affect and are affected by organizational spaces and their atmospheres.

We set this idea into motion by asking students to research the university campus by way of a dérive and to share their experiences through photography and poetic text. They have - so far - always returned to the seminar room loaded with an impressive amount of both everyday sensations of the university's atmospheres and nascent imaginations of how these atmospheres could be assembled differently. Through their accounts we learn about a university campus brimming with affects: fear, boredom, disorientation, growth, exhaustion, laughter, sometimes joy; and discoveries: glimpses of so far unknown or unacknowledged spaces and potentialities, with some students drifting off campus into the nearby forest or the town's alleys, returning with imaginations of how these spaces could enhance the university. 
Based on these bodily experiences the students develop elaborate scenarios for a future university, which were discussed not only within the course, but also had repercussions on university level and beyond.

In the wake of a growing recognition of aesthetic, affective and spatial processes in organization and management studies (Beyes and Steyaert, 2012; 2013; Fotaki, Kenny and Vachhani, 2017) scholars have called for learning approaches that account for and give access to organizing as an embodied (Cunliffe and Coupland, 2012), imaginative (De Cock, 2016), and emotional (Hay, 2014) experience. Komporozos-Athanasiou and Fotaki, (2015: 335) and De Cock et al (2013) indeed point out a "crisis of imagination". Many of these recent approaches in management learning acknowledge 'that bodies are central elements of pedagogies' and 'that pedagogy works at visceral and sensual levels, as well as intellectual and imaginative, activating appetites and desire' (Sinclair, 2005: 91). When addressing the body as a sensing part of both organizing and management learning it is not surprising that the material and spatial aspects, i.e. bodily context, attract increasing attention in organizational theorizing (Nash, 2018; Panayiotou, 2015). Some authors consider new or different spaces of learning, such as studios or workshops (Barry and Meisiek, 2015), and others point out the potential of working with and intervening in established spaces and atmospheres of the business school (Michels and Beyes, 2016). Mack (2013: 301) has observed that ' $[\mathrm{t}]$ he challenge for organizational aesthetics is to continue efforts to bring aesthetic ways of knowing into management education practices'. In drawing on the Situationists' ideas, we consider it an important and challenging task to hold to the critical and radical potential of their artistic conceptions as exemplified by O'Neill and Roberts (2020). 
Sensuous approaches to management learning have called upon art and aesthetic theory as one potential source of conceptual and practical inspiration for 'inquiring into the processes and forces that govern, modulate and change the "knots" of what can be sensed, felt, expressed and acted upon' (Beyes, 2016: 115). The study of organizational atmospheres understood as the spatio-material and affective experience of collective processes - has presented one potential way of accounting for the bodily enactment and affective force of organizational space (Borch, 2010; Gherardi, 2017; Michels and Steyaert, 2017). In response to Julmi's (2017: 19) call for further work 'to illuminate the phenomenon of atmosphere in the context of organization and management studies' we suggest that the dérive, defined as a 'mode of experimental behaviour' and 'a technique of transient passage through varied ambiances' (Coverley, 2010: 93) can inform an understanding of organizational spaces. It can thus inspire learning processes that are sensitive to the aesthetics of organizing.We argue that the practice of the dérive makes space for learning about the aesthetics of organizing and organizational space and reveals affective capacities for experiencing and re-enacting these spaces. The dérive allows for a learning process, which unfolds as a sensing: making sense of, and making nonsense out of management and organization. It exploits the idea of '[s]pace as journey [which] entails both pain and pleasure as every movement involves a letting go in order to embrace new realities and new horizons' (Antonacopoulou, 2014: 88). The business school may support the inculcation of (potentially wise) habits (Statler and Salovaara, 2016) and as a space of experimentation, which 'open[s] up management education to the imaginative geographies of spatial production' (Beyes and Michels, 2011: 522).

Cultural theorist Thomas Levin (1996: 117) asserts that 'the specificity of the dérive stems from its combination of both a ludic and a constructive, analytical dimension' and we exploit 
both aspects. The dérive in management education allows for experiencing and reflecting on the spatial and affective encounters that account for much of organizational life but which are rather ineffable. The dérive invites us to address these encounters in a sensitive, reflexive and imaginative way. It makes space for an active learning experience that challenges traditional pedagogy by presenting an ambiguous, multi-valent, open-ended space as the learning medium. It is the experience and re-imagination of that space that constitutes the learning. Alongside the significance of the dérive for the education of future managers, we note its potential for the development of learning environments in business schools. The practice of dérive in management education can serve as an exercise in imagination and reflection for the business school, where

[imagination's] key function could be to provide a counterweight to the actuality of the organizational world and to make us think how we and our organizations might be otherwise, rather than featuring as some kind of super-problem solving device within clearly (even though not explicitly) delineated societal parameters. (De Cock, 2016: 245)

The following section briefly introduces psychogeography and the practice of dérive in a historical context. In the subsequent section we transpose the concept of dérive to the context of the business school and offer examples from our teaching to illustrate the practice of dérive in management education. We then discuss the implications for the development of management education and its spaces, leading to a short conclusion.

\section{Psychogeography and the practice of dérive}

Exploring the interconnectedness of the external geographical and the internal psychological human world has been the objective of many writers throughout the $19^{\text {th }}$ and $20^{\text {th }}$ centuries. Probably most notably, Walter Benjamin's Arcades Project, used Baudelaire's image of the 
'flâneur, the casual wanderer, observer and reporter of street-life in the modern city' (Seal, 2013: n.p.) as a way to navigate the interface between the physical and the imagined. But also Edgar Allan Poe and his description of the Man in the Crowd, Georg Simmel's analysis of The Metropolis and Mental Life and Arthur Schnitzler's Dream Story addressed how the built environment and mental space intertwine. In urban planning the work of Kevin Lynch explores 'the psychological and sensual effects of the physical form of the city' (Lynch cited in Wood, 2010: 190), aiming to reconnect what had been divided by the modern distinction between the physical and mental world. In resonance with these attempts of reconnecting the inside and the outside world of human life the art movement Situationist International and its various members put forth the notion of psychogeography as 'a thorough exploration of the relations between space, time and passions' (Levin, 1996: 117). Tracing the ambiences of urban life and exploring potential ways of transforming the 'society of the spectacle', the Situationists both criticized the ubiquitous atmospheres of consumption and sought their playful re-composition through artistic interventions. Levin (1996: 117) points out that,

[i]f psychogeography is defined as "the study of the precise laws and the exact effects of the geographic environment, built or unbuilt, in terms of its direct influence on the affective behavior of individuals," then its privileged mode of data gathering - the identification, localization, delimitation of unités d'ambiance, their exits and entrances, their defenses, the discovery of "psychogeographic hubs," etc.-is the practice of the "dérive".

The point of dérive is to drop usual motivations for movement and actions and to become a 'marginal native' or a 'professional stranger'. Letting oneself be 'drawn in by the attractions of the terrain' (Debord, 2006a: 62) or simply 'drift' in Nicholson's (2011: 26) translation of the term (see also Smith, 2014), the dérive lets emerge not only unknown perspectives onto but also bodily resonances with physical space. In this sense the dérive can be understood as 
a method for exploring the affective forces of the environment. The drifter's own experiences serve as the main material for such a spatial analysis (Smith, 2014: 50).

The practice of dérive increases awareness of the ways in which we dwell in our everyday spaces and in undoing habitual behaviour, it creates opportunities for re-imagining these spaces and our roles within them. The imaginative force of the dérive surfaces clearly in Debord's (2006a: 62) much quoted definition of the dérive as 'a rapid passage through various ambiences [involving] playful-constructive behaviour and awareness of psychogeographical effects.' Calling for a playful (re)appropriation of space Debord (2006b: 38) sought to develop the dérive as a method for 'the construction of situations, that is to say, the concrete construction of momentary ambiances of life'. A further aspect of the dérive becomes apparent in the writings of the artist and activist Ivan Chtcheglov, a member of Situationist International, who compares the dérive to psychoanalysis. In his Letters from Afar, Chtcheglov (1964) points out that in the practice of dérive the psychoanalytical flow of words is replaced by the flow through a landscape of ambiences, searching for both their subconscious effects and possible exits or points of interventions. Chtcheglov's comparison accentuates how the dérive serves not only as a means of analysing and reconstructing the ambiences of the terrain, but equally as a medium for exploring and potentially changing the capacities of the drifter's body and imagination. Like psychoanalysis, the dérive can potentially reflect who we are and who we could potentially become in the geographies of our daily lives.

Since its development in the context of Situationist art in the 1960s the method of dérive has travelled into multiple disciplines and contexts. However, introducing the practice of dérive 
to the context of management education could easily be mistaken for an insensitive application of a critical artistic method and a cynical provocation of its underlying values. This was the target of art historian Edward Shanken's ire: 'the thoughtlessness and selfishness of so-called scholars (primarily trendy lit-critters [though]) who colonized [Debord's] brilliant ideas and transformed his radical politics into an academic status symbol not worth the pulp it's printed on...' (cited in Home, 1995: n.p.). On the other hand, Home (1995) points out that Debord was keen about the idea of recuperation and the Situationist International strongly embraced the idea of transforming ideas, paintings, and places by radically changing their contexts. This is the sense in which we use Situationist concepts and practices in a reflexive way to transport some of its critical and creative force into management education.

\section{Dérive and the business school}

Transposing a practice from critical art into a business school therefore calls for care with regard to its conceptual re-anchorage, its goals and its practical implications, as well as, as noted above, its sensitivity to its radical politics. We attend to three specific aspects of management education to which the practice of dérive can potentially contribute: experiencebased learning, experimental learning, and imaginative reflection.

Experience-based learning approaches (Kolb and Kolb, 2005) are based on John Dewey's claim that direct, practical experience is what creates knowledge (Statler and Salovaara, 2016: 206). They depart from a management education that 'has drawn from traditional models of pedagogy which focus on the intellectual processes - the transmission of information, techniques, ideas' (Sinclair, 2005: 91) to address learning as a process which 
includes and reflects upon the bodily experience of a learning situation. Most experiencedbased models of learning aim to simulate real world experiences: role-play, case-study based learning and hands-on design or management tasks have become common learning techniques in the business school (see Gherardi, 2009). The practice of dérive invites us to take a less representational or imitative stance, by working with students in the context of their own life-worlds. However, it has received scant attention in business and management research (but see Knowles, 2009) or as an educational tool (but see Rich and Brown, 2012; Hindley, Knowles and Ruth, 2019).

Holtham and Owens (2011), Rich and Brown (2012) and Hindley, Knowles and Ruth (2019) suggest that more research on the pedagogic application of this technique would be valuable. We present the dérive as a technique as a response to their suggestion and to calls for developing learning experiences that are open-ended (Monk et al, 2011), engaged with the world, sensitive, and which attend to the affective capacities of organizations (Gherardi, 2018). Learning then means being receptive to how we dwell in organizational spaces and their atmosphere (Pyyry, 2017a: 23). Psychogeography and the practice of dérive provide us with a way of integrating the mental and the geographical by presenting a practice of dwelling in (and on) the world imaginatively, which entails the 'un-learning' of our established conventions in inhabiting organizational spaces.

To illustrate our ideas, we present accounts of dérives conducted by students on an undergraduate course entitled The Other University, in which they are required to explore spaces of management education and to invent scenarios for future practices and spaces of higher education. The overall purpose of the course is twofold. First, it introduces students to 
spatial and aesthetic perspectives on organizational processes and to methods for analysing and re-organizing (learning) processes spatially and aesthetically. Second, the course serves as an organizational self-reflection, which informs the business school with regard to its teaching formats and its spatial development. The students present their learning scenarios by way of one visual collage and one imaginative textual account per project collated into a booklet circulated to the administrators for university development and the education department, as well as show-casing them at the university's annual "day of teaching". This contribution has received very positive responses from administrators and academics for the insights engendered, but has also encountered critical voices questioning whether such a course suits a business school at all.

The course follows the weekly rhythm of the semester and consists of three consecutive parts: the exploration of the students' experiences of learning inside and outside the business school, the search for trends in society in general and in higher education in particular and, finally, the re-imagination of university spaces and the development of an imaginative future learning scenario. The learning methods include systematic search and analysis of existing literature, excursions to other schools and universities, a reflection through feature films, design thinking methods, poetic writing, visual collages and, last but not least, the dérive.

The course is offered as a full-time (14-week) elective that is open to students from all disciplines (management, law, and economics), but is almost exclusively selected by undergraduate management students. The number of participants ranges between 20 and 40 students per year, most of whom are enrolled as full-time students, with some participants working in part-time jobs. The course visits many places of learning, and is repeatedly 
relocated; it drifts through and outside of the university campus. In the third session of the course the students are required to individually explore the campus and its environment by way of a two-hour dérive and to document their observations and sensations through photography and short poetic accounts. Starting from these experiences the participants in subsequent sessions develop imaginative scenarios for a future university by basing their ideas on literature (and film) and by working with the visual method of a paper collage. The empirical material for this study comes from two cohorts who studied the course in the years 2017 and 2018. It consists of 48 dérive reports (images and poetic vignettes) as well as 87 reflection papers. The dérive reports presented here have been selected to provide a wide spectrum of results (inside/outside/off-campus/urban/forest) and to present inspiring and qualitatively convincing illustration of our ideas.

We present material from all the course sessions to illustrate our thoughts and experiences with dérive in management education and include extracts from the reflection papers that participants wrote at the end of the semester (translated from the students' original German by the authors). In discussing this material, we will suggest that the practice of dérive can inspire business education and its everyday routines in three ways:

\section{1) The dérive as a tool for experience-based education}

We have discussed how artists of the Situationist International movement developed the dérive as a practice for analysing the relationships that people establish with places and how these are experienced in the ambiences of the built environment. Now we explore why researching ambience and atmosphere is important to students of management as a way of addressing the sensuous and affective life of organizations (Michels and Steyaert, 2017). 
The experiential quality of dérive invites different means of reflection and expression: visual, textual, poetic, kinetic and so on. In the course sessions students are invited to explore the atmospheres of learning by drifting in and outside of the university premises while attending to their visceral experiences. The students are asked to then document their encounters by means of one smartphone photograph and a poetic account of their sensations, shared and discussed in a plenary session afterwards. The class presentations and discussion of the various experiences of students in the 2017 and 2018 cohorts took the participants on an atmospheric journey across (and beyond) the campus. They illustrate how the various spaces of the campus were woven into their experiences. For example, one student expressed sentiments prompted by the locker space next to the entrance to the university library.

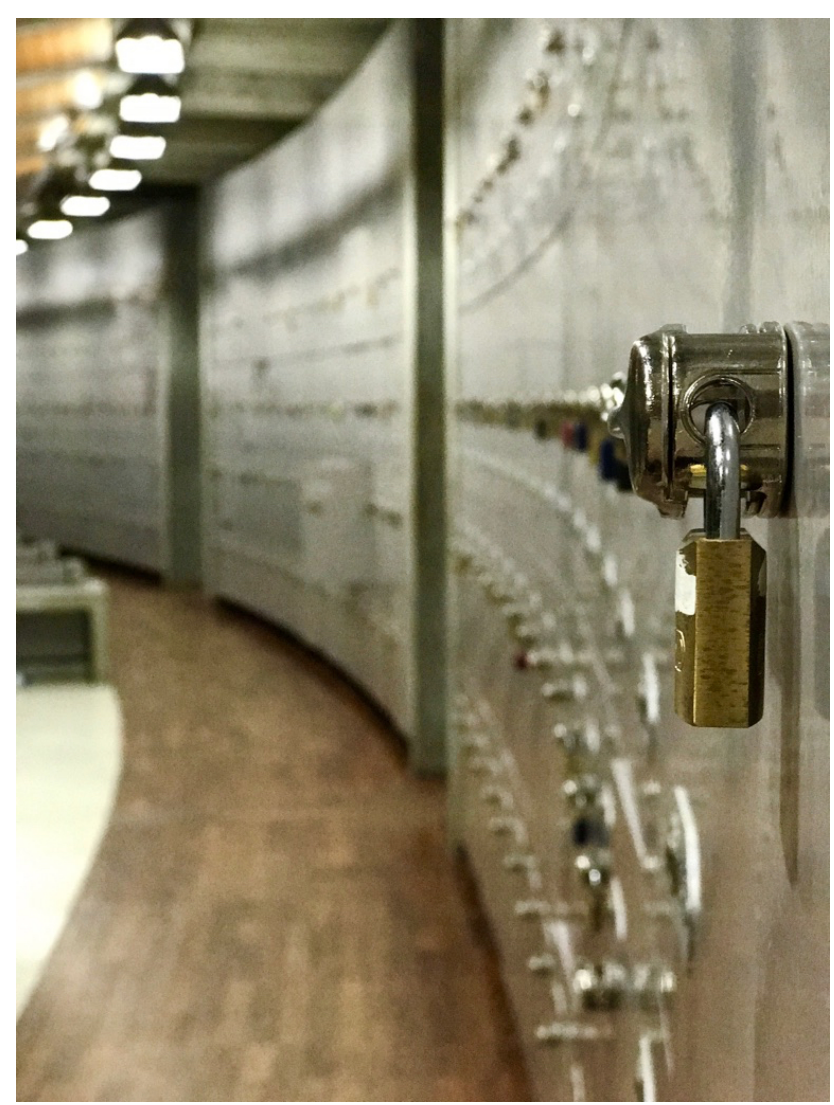


With this image I associate the intense study period at our university. For one month I stand in front of this lock every morning, thinking that I will survive this day too. What a relief when I open the lock for the last time and can go home.

The strain that speaks through the photo, symbolized in the lock, its final opening, and the repetition of the countless locker doors seen in the background, vividly depict the student's everyday experience on campus. These feelings about the university spaces find resonance in the experiences of other participants. For example, another student returned with an exterior photo of the university's main building:

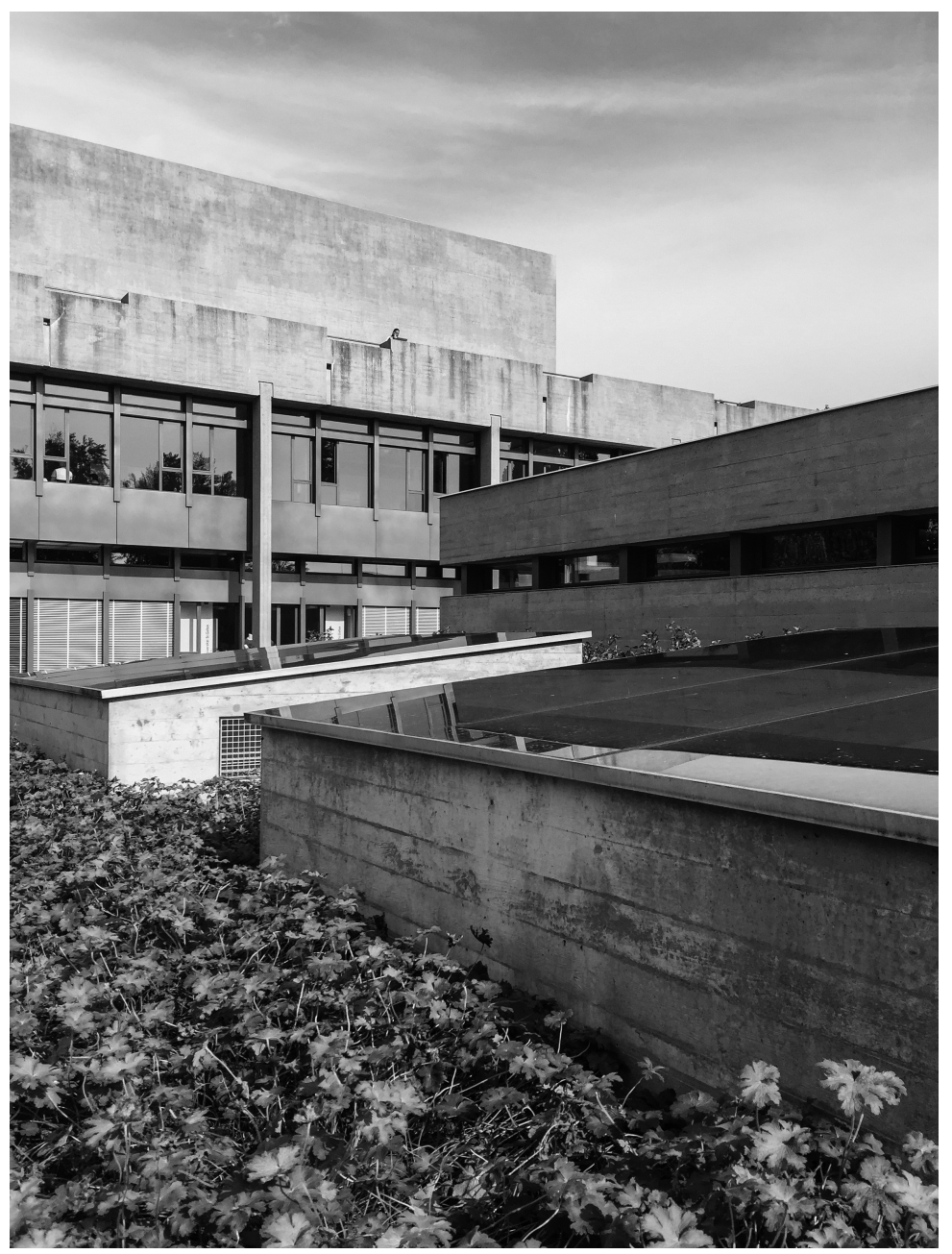

This view of the "head" of the university always gives me food for thought. Even 
though I like the interior I have difficulty to feel anything positive when looking onto the building from the outside. It reminds me of a prison, and since [the architecture] symbolizes the head I feel it's a "head-prison". Creativity and diversity are not being fostered there but inhibited. I don't know how other students feel about it, but I have been haunted by this feeling during the three years I have been studying here.

Taking photographs and capturing their experiences in short written accounts was an unusual and challenging task for the participants. In the daily hassle of student life, there is little consciousness of the actual bodily and sensuous experience of the campus. By turning attention to their bodies and the experience of atmospheres, and by capturing these experiences in photographs and short "poetic" accounts, participants were required to step out of habitualised ways of perceiving their learning environment. Drifting across the campus and its environment without having in mind either their daily routines or a very clear goal, but the task of returning to class with an account of their experience, reveals perceptions of university life otherwise unspoken and unheard:

In the beginning the task of depicting a place which moves us, our thinking, feeling and dwelling, seemed simple. I found the task a bit trivial initially. But the complexity of the task became apparent when I roamed the corridors, stairs and premises while seeking inspiration: Giving free rein to one's emotions, pinning down these emotions and passing on one's inspiration in the form of a picture and text. It was fascinating to learn how my awareness of the various places changed, simply by taking some time and reflecting on their atmospheres.

Another student summarised her memories of the session in the following way:

It was fascinating to see the other students' results: Most of the representations told of stress and pressure, of students that were alone and isolated in what we call "bulimia learning", during the intensive study period. Others showed places on campus which allow unwinding from the everyday stress.

While the students' experiences show many overlaps and patterns there are also differences resulting in spirited discussions about the atmosphere of the campus, many of which concern 
varied perceptions of the university's architecture and its art collection. By comparing their experiences to those of other students and discussing the differences and similarities, the multiplicity and complexity of university spaces and how they are experienced became apparent. Students assessed and reflected on how organizational atmospheres come about, how they emerge from individual and collective memories, and how they can be perceived differently. By paying attention to the variety of the ways they experience organizational spaces, the students addressed how they are themselves implicated in the atmospheric performances of the university.

In this first section, we have focused on the way in which the dérive serves as a means of attending to the aesthetics of organizing through the body. The exercise of drifting on and off campus allows participants to develop an experience-based understanding of how the psyche is interwoven with the physical environment of organizations and how both are experienced in (habitualised) human bodies. As lecturers we feel that the learning about organizational psychogeographies is substantially aided by the use of photography and poetic writing. In their performative capacity both methods (in combination) support the participants in searching for, assembling and sharing experiential accounts. Presenting their findings in this rather unfamiliar artistic format requires the ability to observe, empathize and synthesize inputs of different qualities and made way to perform organizational accounts that bring to the fore the affective life of organizing.

2) The dérive as a technique for experimental learning 
Through the dérive one may attend to and reflect on the bodily experience of space. The dérive also provides a tactic for systematically creating encounters with the unusual and unforeseeable thereby enhancing creative potential and igniting imagination. Moving one's body through space can become a systematic exploration of and experimentation with the affective capacities both of human bodies and of the material environment of more or less familiar spaces of organizing. Unsettling the habitual scripts of organizations allows us to sense and to learn about what could potentially be done by our bodies and the spaces they inhabit.

The dérive can be a way of re-imagining organizational spaces and one's role in them, an exercise in dreaming or imagining, through which students explore the capacities of their bodies and minds in relating to organizational spaces. The following accounts illustrate how the dérive inspired the imagination. While the drifts across the university campus revealed usually unspoken of experiences of university atmospheres, drifting off campus proved particularly productive with regard to fresh imaginations of university life. One student came back with a picture of a sun-lit alley and shared her vision of bringing the university closer to the city centre. 


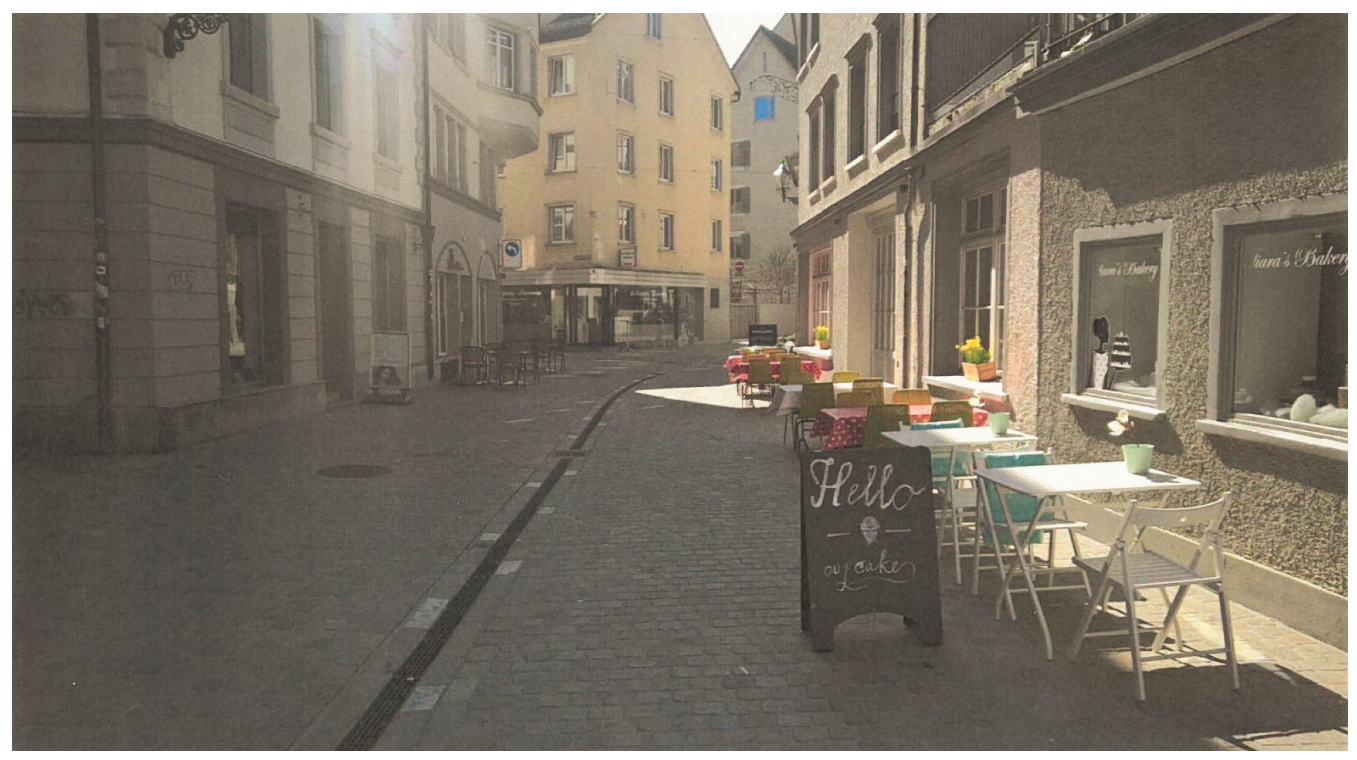

Right across the street, there is a nice alley. The board and the carefully dressed tables are inviting. But not a living soul is to be seen. I imagine how coffee-loving and hungry students could bring to life this abandoned alley.

It is no surprise that the town comes into play as a resource for imagination. City life with its richness of diversity and density presents a highly inspiring environment for encountering the unexpected and thus for questioning, reflecting on, and re-imagining what may hitherto have been taken for granted. For the Situationists the city served as a key site for atmospheric analyses and artistic interventions epitomised in Debord's famous "naked city map". However, the Situationists were not confined to urban space. Disorientation and wonder could also be found when drifting through the German Harz Mountains, guided by a London street map (Debord, 1955 cited in McDonough, 1996). Similarly, some of the participants from the classes drifted off campus and entered the nearby forest, returning to class with patches of moss, leaves and stones. The poetic text and a collage that was developed as part of a group project condense their experience: 


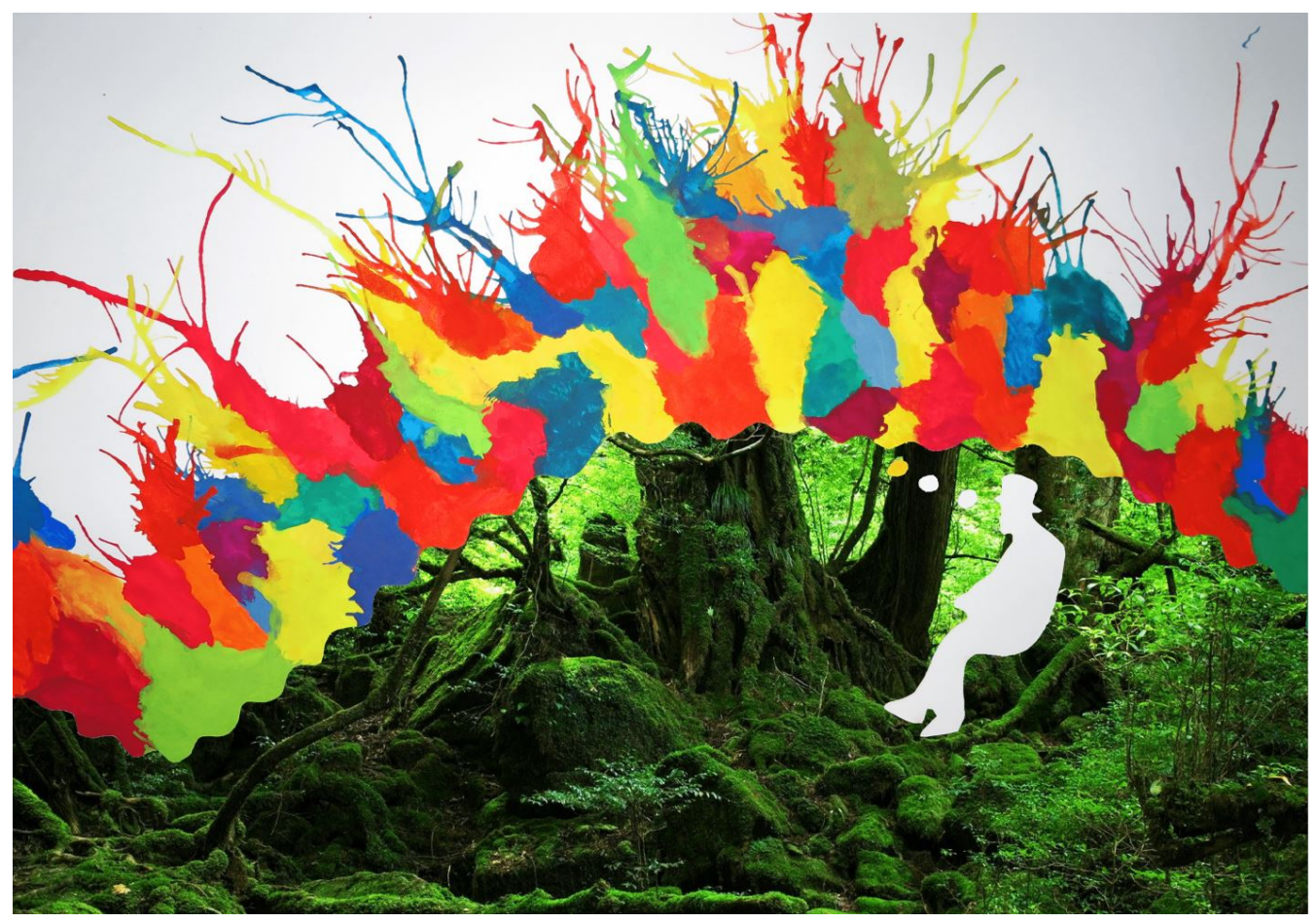

Who doesn't know it? You are sitting in the library, stiff back, buttocks hurting, mind blocked, and motivation gone. The exams are waiting to be studied for, papers are waiting to be written, you should be grinding away, ideas should be flowing, but nothing happens. Inspiration is lacking, no fresh air, no sun, instead stress, pressure, competition, peer pressure, digitalization, studying as if there was no tomorrow. But actually, you want to be outside, experiencing the world, exploring yourself. Off to the woods!

This experience inspired the group to develop a project which cultivates the forest as a future space for learning and recreation. In their reflection paper these participants say that 'even though we did not use any of the pictures [taken that day], the experience we had in the woods was a key moment of our process. The feelings of comfort and relaxation nourished our plan to develop the Park of Ideas'. Stepping out of the everyday routines and spaces of education was anything but a self-evident task for the students. The following student quote reflects an understanding of how the university's organization, its boundaries and constraints are firmly inscribed in the participants' bodies, the way they move, feel and find comfort: 
I remember vividly how on that day I had the feeling that I was wasting precious time with a useless stroll instead of following my more relevant study commitments. The discomfort resulted less from the challenging and unconventional task but rather from the fact that for an afternoon we had to let go the mind-set of efficiency and to give way to a pleasantly hubristic occupation. I let myself drift, meandered from one place to the next and learned about the atmosphere from within different situations and perspectives. [...] Apart from engaging in some exercise rich in movement, we profited by developing a new understanding of space and new inspirations, which influenced our group work fundamentally.

Obviously, these students have been in the city and woods before, but they have not roamed these spaces while seeking inspiration for a different university campus. These accounts show how a dérive through city alleys or woods with the university's space in mind can trigger the imagining of alternative organizational spaces just as the Situationists sought to make the familiar strange by changing their perspective of the Harz Mountains by superimposing the London street map on their perceptions. The specific quality of these forms of spatial encounters consists of addressing the entire body with all its senses as well as the multiplicity and complexity of urban and natural life.

While the first empirical section dealt with the experiential qualities of drifting and its potential of making the aesthetics of organizing addressable, in this second section we have focussed on the experimental value of the dérive. Even though the course does not systematize the "derailing" of habitual ways of moving through space to the extent the Situationists did through their superimpositions (and use of drugs), the students' findings reveal the potential of getting lost (e.g. the town, the woods) for developing new perspectives and unsettling taken for granted assumptions. The dérive facilitates unforeseen encounters and wandering about becomes wondering about the spatiality of organizing. We would argue that experimenting with the affective capacities of organizational spaces through the dérive contributes to learning about the (im)possibilities of unsettling organizational routines and 
making space for new forms of sensing and imagining. However, starting an imaginative work process with a bodily experience requires a readiness to embrace the uncertainty that comes with navigating without a clear destination.

\section{3) The dérive as a practice for imaginative reflection}

In this third empirical section we show how the process of opening up, (re-)sensing and (re-) imagining organizational atmospheres is one way of becoming reflective about the way organizations are enacted and how one participates in them. Statler and Salovaara (2016) discuss how students might become reflective about the processes of habituation which shape our individual and collective experiences of organizational processes. We would like to suggest that the dérive is a potentially fruitful practice of stepping out of everyday habits by disrupting and reimagining the organizational spaces and the way they are experienced.

As we have seen, one way of disrupting the atmospheres of organizational spaces is by making the familiar appear unfamiliar. This de-familiarisation is a recurring theme in academic literature on organizational change and learning. Pyyry (2017a: 22) for example states that 'learning can be an unspecific fleeting moment of looking at familiar spaces and things differently.' Beyes and Steyaert (2013) introduce the concept of 'unsiting' to organization studies in order to grasp a spatial process of making the familiar strange. They see 'unsiting' as a tool that allows us to encounter the affective forces of organizing (p. 1461) and they claim 'that what alters the way we experience these sites [of encounter] will alter the way we can experience, conceptualize and shape organization' (Beyes and Steyaert, 2013: 1462). De Cock (2016: 246) draws on Castoriadis to suggest that imaginative 'business 
school teaching would therefore induce us to render strange what has become familiar and aim to unsettle the fundamental social imaginaries that hold us all in thrall.'

While some students struggled to write about their experiences and simply gave accounts of how they use various spaces on campus, most accounts described the way university spaces make them feel in their everyday routines. These experiences were taken up in the many projects that dealt with the themes of reinvigoration and stress prevention: for example, by cultivating university gardens, turning canteens into laboratories for diversity, collaborating with an animal shelter, gamifying learning processes, creating digital-detox zones, and preventing loneliness through spaces of encounter. In other cases, the dérive triggered the participants' imagination in a more immediate manner. The encounter with other environments during the dérive unsettled the participants' imagination of what a business school could potentially feel like, and thus made space for controversy and reflection on the everyday performances of university life.

For instance, one group roamed the city and created the idea of providing movable boxes for students to inhabit other learning environments. This idea was fueled by the rather distant relationship between university and the city and the aloof image the university has among citizens. However, when this group presented their idea to a member of the government their imagination was met with skepticism. 


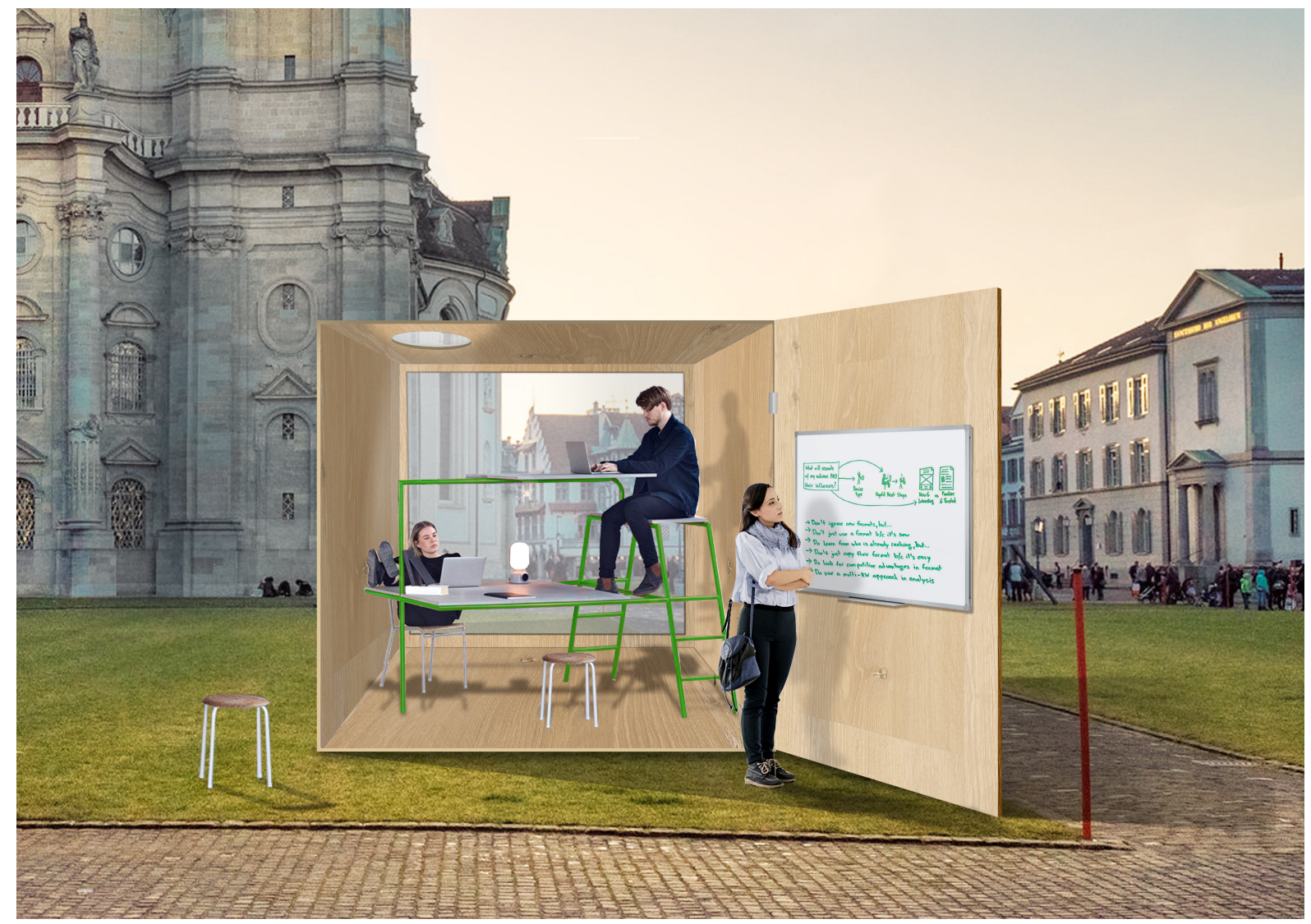

'these boxes are nice, but I am wondering if they actually help in bringing the university closer to the citizens. I could imagine that they produce the contrary effect. Simply because these boxes are located in the city, it doesn't mean that all of a sudden there will be more interaction and discussion. And as long as they are exclusively open to university students, the boxes reflect a two-tier society right under our nose. But I am curious and happy to be convinced otherwise.' (from a student interview with the councillor for education, our translation)

Another group's project for a concentrated learning zone entitled "Escape Circle: Finding focus in the age of distraction" was fiercely debated among fellow students at its presentation. While some welcomed the idea of a panoptical architecture that would support students in focused learning, others argued that the project presented a dystopian nightmare rather than a promising future. Some students felt that the suggested project did not greatly 
differ from how they experience the university today and that it would be only reasonable to provide an architecture that supports this kind of learning process.

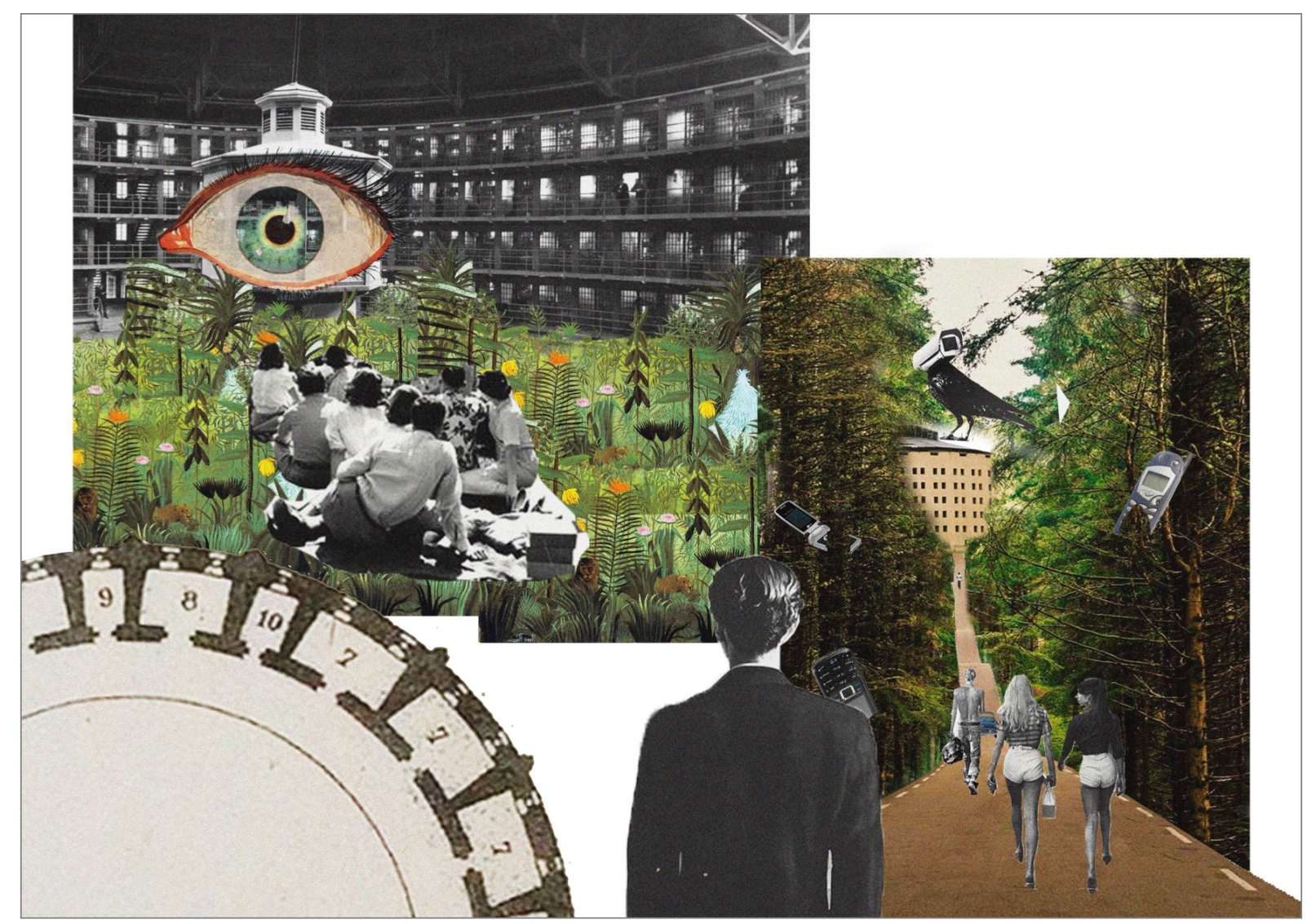

In both cases the spatial imaginations of another university started with and drew from the experience of drifting on and off campus, using the body as a tool for aesthetically exploring and reimagining university life. Mediated by the means of visual collages and poetic writing, the groups' imaginations did not present ultimate answers for the future university but prepared the ground for a discussion on how the university should (or should not) develop in the future, in terms of how it could feel to study there and how its atmospheres could potentially be composed and enacted. 
This exercise in reimagining university life also created tensions on the level of university management. In a phone call with the lecturer, a member of the university's administration expressed worries about the university's reputation in case the students' proposals became public in the local media. Furthermore, it was questioned if this kind of seminar was suitable for a business school at all. On the other end of the spectrum, the student union's presidents became regular participants in the course, praising it for developing a students' perspective on university and campus development. This assessment was also taken up by the university's department of "Business Education", by some of the members of the campus design team, as well as by external experts of university development from neighboring institutions, all of them showing their interest by attending the final presentations of the student projects. In addition, the projects were presented to the planning committee for a new learning centre and to a wider audience of professors and teachers at the university's yearly "Day of Teaching", which serves as a moment of reflection on the current state and potential future of education at the university. All of these presentations were met with as much enthusiasm as silent doubt, critical debate and sometimes outright rejection of both the course's outcomes and its design. These ambivalent reactions to the course were mirrored in the feedback of participants, where some students expressed their doubts about letting go (for a moment) of the analytical and cognitive ways of working in which they had been educated. In their reflection papers and course feedback some students related their 'difficulties with developing spatial imaginations', their frustrations with 'haphazard aesthetic methods' that produced unpredictable outcomes, and their reservations about the usefulness of these experiences in their future professions as managers. 
What we may note in this section is that although the irritations of both participants and the university as an institution were benign and rather mild, they display the power of imagination for controversially opening up potential spaces of future universities, and thus can serve as a process of reflection both on individual and organizational level. KomporozosAthanasiou and Fotaki (2015, S. 336) argue that

'by claiming our power to imagine organizations differently we embody the project of political autonomy. Such an outlook, both critical and productive, is conspicuously absent in existing accounts of predicaments faced by the organizations of today and is, in our view, more important than ever in attempts not only to understand these predicaments, but also to look for ways of moving forward towards imagining the social differently'

Barnett $(2013,2018)$ has argued that today universities lack this kind of imaginative autonomy which would enable them to go beyond the discourses of the "entrepreneurial university" and to reinvent their role in society. Despite the obvious limitations to changing the practices and narratives which co-produce university life, we would argue that it is the adumbrated potentiality of another university, in the sense of an axis of passage (Debord, 2006a), that triggers imagination and thus opens up spaces for reflection on the everyday atmospheres of the university.

Drawing a more general conclusion from all three empirical parts we would like to underline the dérive's potential for promoting an understanding of organizational atmospheres as a process that is brimming with affects, depends on passionate experimentation, and involves the body with its imaginative potential. Here, learning is neither about efficient knowledge transfer nor about 'filling that which is empty. Instead, it is about dis-covering the intensity of 
the experience of learning to create connections when and where these were not thought possible' (Antonacopoulou, 2014: 89).

Management education scholars have pointed out the importance of a critical pedagogy 'that pushes participants to notice how they are inter-penetrated by complex assemblings of relationships and to recognize radical possibilities and novel patterns that are continually emerging in surprising ways' (Fenwick, 2016: 258). Such a pedagogy makes use of a 'critical attunement' as a way of imagining and inventing alternative forms of organizing. The practice of dérive starts with one's own involvement and playfully opens an experiential space, an atmosphere, in which imagination can flourish and thought experiments take place.

Grasping organizations as sites of psychogeography, and the dérive as a means of learning about them and one's place within them facilitates moments of enchantment and it fosters learning as a process of imaginative reflection. By this form of reflection we mean an understanding of the contingencies of organizational life and the awareness of alternative ways of experiencing and participating in its unfolding. Although we agree with Pyyry (2017a: 29) that 'reflection is something that hits us, rather than something we "do"”, we would like to point out that the dérive involves quite a bit of 'doing' that prepares and leads to these unexpected moments of reflection. Reflection here emerges from intervening and experimenting with organizational life, and is not a purely cognitive process. Cognitive reflection may depend on removing oneself from a situation in order to think about it from the "outside". The form of reflection that we experienced with the practice of dérive actually works the other way around: only by putting oneself in the midst of organizational life and 
intervening in its routines does one become aware of potential ways of performing it differently.

\section{Re-imagining management education through the dérive}

In the discussion, we will focus on how the practice of dérive can inform management education and contribute to a more reflexive spatial development of institutions of higher education. We will begin by addressing how understanding the aesthetics of organizational spaces and developing one's affective capacities of experiencing and re-enacting these spaces through the dérive contributes to the education of future managers. Inviting students of management to drift through university space and to imagine potential future scenarios of its organization might seem a confused and romantic approach for preparing these students for their future work environment, filled with deadlines, spreadsheets and strategic decision making. Surely, one may point out, it is rather unlikely that investment banks, tech companies or pharmaceutical industries will employ managers to meander across and off their premises, while dreaming up alternative organizational atmospheres. Furthermore, the business school is fundamentally different from the potential future work environments of its students and therefore is not suitable as an organizational learning place.

While it is impossible to know (and hard to imagine) the emergent needs of future organizations and the practices of their managers, our motivation to promote the dérive in management education is based on the following observations. First, recent organizational research (De Cock et al, 2013; Komporozos-Athanasiou and Fotaki, 2015: 335) has pointed out that today we are facing a "crisis of imagination" in the contexts of organization, economy and society, and that there is need for exploring imaginative modes of participating 
in organizations. While there has been a broad paradigmatic shift towards 'creativity' and 'innovation' in organization and management studies, this shift has been criticised for its instrumental and often unpolitical nature (Hjorth et al, 2018). The notion of imagination seems, in this regard, to provide a remedy.

The dérive is one of many ways ${ }^{1}$ of fostering imaginative reflexivity in business education and management practice. Teaching students to do dérives is not our goal; rather, we hope that the dérive sensitises students to the aesthetics of organizing and the potential of approaching organizations from sensuous and experimental perspectives. Accepting that '[o]rganization is invariably an atmospheric phenomenon [which] takes shape as a swirl of affect, constructed from constellations of objects, stories, technologies, texts, human bodies and their affective capacities' (Beyes, 2016: 115) we propose the dérive as an ideal means to learn about the affective forces of organizations and to reimagine their atmospheres. As the empirical section of the paper shows, the combination of experiential and experimental learning allows for the emergence of an 'imaginative reflexivity' which foregrounds the 'poetic' in politics and asserts it as 'an activity of reconfiguration of that which is given in the sensible' (Rancière and Panagia (2000) cited in Komporozos-Athanasiou and Fotaki, 2015:334). Re-imagining, then, becomes crucial because ' $[t]$ he way in which we imagine the organizations we inhabit (through producing images, meanings and emotions) has a concrete

${ }^{1}$ Other imaginative approaches to organizing include the production of fictional accounts (Savage et al, 2017) and the use of poetry (Van Buskirk et al, 2018). 
effect on the actions we take within them when pursuing our individual and organizational objectives' (Komporozos-Athanasiou and Fotaki, 2015: 322).

Secondly, the university serves as a suitable environment, as a heterotopic place (Beyes and Michels, 2011), for experimenting with new practices and reflecting on the predominant habits of managerial practice. If we wish to foster practices that are reflexive of habits, can there be a better place to do so than the organization, such as the business school, that one participates in on a day-to-day basis? However, in the context of MBA training, it might be more productive to actually work with the spaces of the participants' work environment. This being said, it seems unfruitful to limit students in their choices of where to do dérives; as our illustrations show, leaving the defined spaces of an organization (drifting off campus) holds huge imaginative potential. The practice of dérive requires a moment of open exploration and uncertainty. Finding the suitable or appropriate place is part of the research process. The 'wrong' place does not really exist, although as objectives develop some places may be deemed more appropriate dérive locations than others. In fact, it might serve the learning process to avoid deflating the tension around the insecurity that accompanies every dérive but rather dare to " "hold students in the moment" so they can understand their experiences through feeling them' (Beyes, Parker and Steyaert, 2016: 11).

Thirdly, we would like to suggest that the practice of dérive is particularly interesting with regard to 'the psyche': '[A]lthough important discussions around the politics of affect, alternative spacings and politics of the "here and now" [...] acknowledge the value of understanding sentiments, passions and personal morality [...], they have less to say about the space in which they are generated: the human psyche' (Komporozos-Athanasiou and 
Fotaki, 2015: 334). The concept of psychogeography, which we see as the underlying concept of the dérive, offers a promising way of interweaving the psyche with the physical environment and the (habitualised) human body. The dérive, as a spatial form of psychoanalysis (Chtcheglov, 1964), provides a practical way of working (or rather playing) with the hidden desires and their potentialities that emerge from unsettling the geographies of our imagination and may promote 'the subject's ability to open up to new (affective) spaces that can be constitutive of new political practices' (Komporozos-Athanasiou and Fotaki, 2015: 334).

Fostering the ability to observe, empathize and synthesize inputs of different qualities, the dérive teaches management by 'wandering about'. This tactic of prising open organizational imagination, one's role in it or the stories about it, can be seen as a form of what Cassell et al (2009: 517) have described as being 'context-wise'. Their concept of 'phronesis' - of being 'street smart' - as 'knowledge [that] consists of acting from what one knows to "make things happen" links with psychogeography as we are requiring students to literally go out and act smartly on the street to make their learning "happen"” (Zackariasson, Styhre and Wilson, 2006: 421) and to experience how 'thinking emerges in unforeseen encounters' (Pyyry, 2017b: 1391).

Whilst we have focused our discussion on the educational implications of carrying out dérives, we would like to also reflect on the dérive as an organizational practice that promotes an imaginative reflection on the business school itself. The buildings of law schools or business schools socialize students into 'role expectations of power and authority, wealth, comfort and an appreciation of upper class culture' (Costello, 2001: 58) and provide and re- 
produce a very specific atmosphere. In light of this we suggest that the practice of dérive provides a helpful approach for reflecting and potentially changing these ambiences of learning by exploring new ways of moving in and outside the business school. The imaginations of an 'other university' that emerged through the dérive showed learning spaces that are in resonance not only with the students' desires but also with pressing societal issues such as social isolation, toxic stress and ecological degradation.

Before starting to re-design 'smart and exciting environments in order to attract and retain students' (Lambert, 2007: 1), business schools might be well advised to first re-enact and thus to experiment with the ways in which students dwell in their learning spaces. While many institutions of higher education - not only business schools - have realized that the learning environment is important and that learning spaces can be more or less inspiring (Berti, Simpson and Clegg, 2018), few have actually started to explore the potentialities of their existing campuses, not to mention the imaginative capacities of their staff and students. In undoing and re-imagining our schools, we suggest taking our cue from Debord (1958, cited by Levin, 1996: 113):

We must construct new ambiances that are simultaneously the product and the instrument of new modes of behaviour. In order to do this, we must employ in an empirical fashion, initially, the quotidian activities and the cultural forms that already exist at this moment, even as we deny them any inherent value.

Dérive then becomes one way of working with and opening up the classroom, by changing the habits of education, for example, by encouraging students to leave the classroom and to start to playfully explore the potentials of re-encountering what exists already in their environment. As the outcomes of our course show, the dérive inspired imaginations of a 
future university do also have implications for re-designing its physical spaces. An imaginative and reflexive design practice could therefore incorporate Levin's (1996: 115) suggestion that '[a]ny future building must be preceded by a thorough investigation of the relationship between spaces and feelings, between form and mood.' Taking note of and seeking inspiration from its students' imagination would prevent business schools from unreflectively adapting design trends that currently sweep through the spaces of institutions of higher education (Boys, 2015; Barnett, 2018).

Whilst the response to our efforts to promote imaginative reflection on the business school in our course was met with ambivalence, we remain encouraged by Dey and Steyaert (2007: 453) to 'belie[ve] in the potency of imagination and invention that subverts fixed knowledge, and notably university (business school) curricula.' We would therefore like to conclude by reiterating our claim that the dérive - as a way of combining experiential, experimental and reflective learning - will not only 'make management teaching more meaningful for students' (Gherardi, 2016, p. 267) but is also a way of keeping management education and the business school alive, imaginative and critical.

\section{Acknowledgements}

The authors would like to thank all participants from the course Die andere Universität: Atmosphären der Forschung und Lehre, and in particular Carla Allen, Chiara Bolter, Janek Brochocki, Nicole Brühwiler, Serafin Fürbringer, Nick Huber, Jasmina Jakupovic, Leonie Leser, Monika Nef and Robin Röösli for the permission to publish their beautiful collages. We thank Dalal Elarji for carefully proofreading the article.

\section{Funding}

The author(s) disclosed receipt of the following financial support for the research, authorship, and/or publica- tion of this article: Financial support by the Liechtenstein Research Funding Commission (Liechtensteiner Forschungsförderungsfons FFF) Project "Organizing Spaces of Creativitiy and Reflexivity (OSCAR), Project No. AR_2_17” is gratefully acknowledged. 


\section{References}

Antonacopoulou, E. P. (2014) The experience of learning in space and time, Prometheus, 32(1): 83-91.

Barnett, R. (2013) Imaging the University. London: Routledge.

Barnett, R. (2018) The Ecological University: A Feasible Utopia. London: Routledge.

Barry, D. and Meisiek, S. (2015) Discovering the Business Studio. Journal of Management Education 39(1): 153-175.

Berti, M. Simpson, A.V. andClegg, S. (2018) Making a place out of space: The social imaginaries and realities of a Business School as a designed space. Management Learning 49(2): 168-186.

Beyes, T. (2016) Art, aesthetics and organization. In: Czarniawska, B. (ed) A Research Agenda for Management and Organization Studies. Cheltenham: Edward Elgar, pp. 115-125.

Beyes, T. and Michels, C. (2011). The production of educational space: Heterotopia and the business university. Management Learning, 42(5), 521-536. https://doi.org/10.1177/1350507611400001

Beyes T., Parker, M. and Steyaert, C. (2016) Introduction: why does management education need reinventing? In: Steyaert, C, Beyes, T. and Parker, M. (eds) The Routledge Companion to Reinventing Management Education. London: Routledge, pp. 198311.

Beyes, T. and Steyaert, C. (2012) Spacing organization: non-representational theory and performing organizational space. Organization 19(1): 45-61.

Beyes, T. and Steyaert, C. (2013) Strangely Familiar: The Uncanny and Unsiting Organizational Analysis. Organization Studies 34(10): 1445-1465.

Borch, C. (2010) Organizational Atmospheres: Foam, Affect and Architecture. Organization 17(2): 223-241.

Boys, J. (2015). Building better universities: Strategies, spaces, technologies. New York: Routledge.

Cassell, C., Bishop, V., Symon, G., Johnson, P. and Buehring, A. (2009) Learning to be a Qualitative Management Researcher. Management Learning 40(5): 515-533.

Chtcheglov, I. (1964) Letters from Afar. Internationale Situationniste \#9: n.p. Retrieved from https://www.cddc.vt.edu/sionline/si/letters.html 
Costello, C.Y. (2001) Schooled by the Classroom: The (Re-)production of Social Stratification in Professional School Settings. In: Margolis, E. (ed) The Hidden Curriculum in Higher Education. London: Routledge, pp. 61-78.

Coverley, M. (2010) Psychogeography. Harpenden: Pocket Essentials.

Cunliffe, A. and Coupland, C. (2012) From hero to villain to hero: Making experience sensible through embodied narrative sensemaking. Human Relations 65(1): 6388 .

Debord, G. (2006a) Theory of the Dérive. In: Knabb, K. (ed), Situationist International Anthology. Berkeley: Bureau of Public Secrets, pp. 62-66.

Debord, G. (2006b) Report on the Construction of Situations and on the International Situationist Tendency's Conditions of Organization and Action. In: Knabb, K. (ed) Situationist International Anthology. Berkeley: Bureau of Public Secrets, pp. $25-43$.

Dey P and Steyaert C (2007) The Troubadours of Knowledge: Passion and Invention in Management Education. Organization 14(3): 437-461.

De Cock, C. (2016) From creativity to imagination with Cornelius Castoriadis. In: Steyaert. C., Beyes, T. and Parker, M. (eds) The Routledge Companion to Reinventing Management Education. London: Routledge, pp. 234-248.

De Cock, C., Rehn, A., and Berry, D. (2013). For a critical creativity: The radical imagination of Cornelius Castoriadis. In K. Thomas and J. Chan (Eds.), Handbook of research on creativity. Cheltenham: Edward Elgar, pp. 150-161.

Fenwick, T. (2016) What matters in sociomateriality: towards a critical posthuman pedagogy in management education. In: Steyaert $\mathrm{C}$, Beyes $\mathrm{T}$ and Parker $\mathrm{M}$ (eds) The Routledge Companion to Reinventing Management Education. London: Routledge, pp. 249-263.

Fotaki, M., Kenny, K. and Vachhani, S.J. (2017) Thinking critically about affect in organization studies: Why it matters. Organization 24(1): 3-17.

Gherardi, S. (2009) Knowing and Learning in Practice-based Studies: An introduction. The Learning Organization 16(5):352-359.

Gherardi, S. (2016) The practice-turn in management pedagogy: A cross-reading. In: Steyaert, C., Beyes, T. and Parker, M. (eds) The Routledge Companion to Reinventing Management Education. London: Routledge, pp. 264-270.

Gherardi, S. (2017) One turn ... and now another one: Do the turn to practice and the turn to affect have something in common? Management Learning 48(3): 345-358. 
Gherardi, S. (2018) Theorizing affective ethnography for organization studies. Organization. Epub ahead of print 1 November 2018. DOI: 10.1177/1350508418805285.

Hay, A. (2014) 'I don't know what I am doing!': Surfacing struggles of managerial identity work. Management Learning 45(5): 509-524.

Hindley, C., Knowles, D., and Ruth, D. (2019) (online). Teaching research methods: Introducing a psychogeographical approach. Journal of Management \& Organization, 1-13. Doi:10.1017/jmo.2019.15

Hjorth, D., Strati, A., Drakopoulou Dodd, S., andWeik, E. (2018). Organizational Creativity, Play and Entrepreneurship: Introduction and Framing. Organization Studies, $39(2-3), 155-168$.

Holtham, C. and Owens, A. (2011) Using the urban to span the boundaries between diverse disciplines: Drama Education and Business Management. Practice and Evidence of Scholarship of Teaching and Learning in Higher Education 6(3): pp. 292-305. Retrieved from http://core.kmi.open.ac.uk/display/1665899

Home, S. (1995) "The perfection of suicide lies in ambiguity". Transgressions: A Journal of Urban Explorations, 1. Retrieved from https://www.stewarthomesociety.org/debord.html

Julmi, C. (2017) The Concept of Atmosphere in Management and Organization Studies. Organizational Aesthetics 6(1): 4-30.

Knowles, D. (2009) Claiming the Streets: Feminist Implications of Psychogeography as a Business Research Method. The Electronic Journal of Business Research Methods 7(1): 47-54.

Kolb, A.Y. and Kolb, D.A. (2005) Learning Styles and Learning Spaces: Enhancing Experiential Learning in Higher Education. Academy of Management Learning \& Education 4(2): 193-212.

Komporozos-Athanasiou, A., and Fotaki, M. (2015). A Theory of Imagination for Organization Studies Using the Work of Cornelius Castoriadis. Organization Studies, 36(3), 321-342.

Lambert, C. (2007) Exploring new learning and teaching spaces. Warwick Interactions Journal 30(2). Retrieved 22.01.2019 from http://www2.warwick.ac.uk/services/ldc/resource/interactions/current/ablambert/l ambert

Levin, T.Y. (1996) Geopolitics of hibernation: the drift of situationist urbanism. In: Andreotti, L. and Costa, X. (eds) Situationists art, politics, urbanism. Barcelona: Actar, pp. 111-164. 
Mack, K. (2013) Taking an aesthetic risk in management education: Reflections on an artistic-aesthetic approach. Management Learning, 44(3), 286-304. https://doi.org/10.1177/1350507612442048

McDonough, T. (1996) The dérive and situationist Paris. In: Andreotti, L. and Costa, X. (eds) Situationists art, politics, urbanism. Barcelona: Actar, pp. 54-72.

Michels, C. and Beyes, T. (2016) Spaces with a temper: On atmospheres of education. In: Steyaert, C., Beyes, T. and Parker, M. (eds) The Routledge Companion to Reinventing Management Education. London: Routledge, pp. 312-329.

Michels, C. and Steyaert, C. (2017) By accident and by design: Composing affective atmospheres in an urban art intervention. Organization, 24(1), 79-104.

Monk, N., Chillington Rutter, C., Neelands, J. and Heron, J. (2011) Open-Space Learning: A Study in Transdisciplinary Pedagogy. London: Bloomsbury.

Nash, L. (2018) Performing Place: A Rhythmanalysis of the City of London. Organization Studies, 0170840618789161. https://doi.org/10.1177/0170840618789161

Nicholson, G. (2011) The Lost Art of Walking. Chelmsford: Harbour.

O’Neill, M. and Roberts, B. (2020). Walking Methods. London: Routledge, https://doi.org/10.4324/9781315646442

Panayiotou, A. (2015) Spacing gender, gendering space: A radical "strong plot" in film. Management Learning, 46(4): 427-443. https://doi.org/10.1177/1350507614541200

Pyyry, N. (2017a) Geographies of Hanging Out: Playing, Dwelling and Thinking with the City. In: Sacré, H. and De Visscher, S. (eds) Learning the City. Springer Briefs in Education. Cham: Springer, pp. 19-33.

Pyyry, N. (2017b) Thinking with broken glass: making pedagogical spaces of enchantment in the city. Environmental Education Research 23(10): 1391-1401.

Rich, M. and Brown, A. (2012) Combining formal and informal learning for undergraduate management students based in London. In: Van den Bossche, P., Gijselaers, W.H. and Milter, R.G. (eds) Learning at the crossroads of theory and practice: Research on Innovative Learning Practices, Heidelberg: Springer, pp. 23-36.

Savage, P., Cornelissen, J. P., and Franck, H. (2018). Fiction and Organization Studies. Organization Studies, 39(7), 975-994.

Seal, B. (2013) "Benjamin and the Birth of the Flâneur", Psychogeographical Review 14.11.2013 URL: http://psychogeographicreview.com/baudelaire-benjamin-andthe-birth-of-the-flaneur, last accessed 12/01/2020. 
Sinclair, A. (2005) Body and Management Pedagogy. Gender, Work and Organization 12(1): 89-104.

Smith, P. (2014) On Walking ... and Stalking Sebald. Axminster, Devon: Triarchy Press

Statler, M. and Salovaara, P. (2016) Thinking in and of the world: Actualizing wisdom and pragmatism in business education? In: Steyaert, C., Beyes, T. and Parker, M. (eds) The Routledge Companion to Reinventing Management Education. London: Routledge, pp. 206-220.

Steyaert, C., Beyes, T. and Parker, M. (eds) (2016) The Routledge Companion to Reinventing Management Education. London: Routledge.

Van Buskirk, W., London, M., and Plump, C. (2018). The Poetic Workspace. Journal of Management Education, 42(3), 398-419.

Wood, D. (2010) Lynch Debord: About Two Psychogeographies. Cartographica: The International Journal for Geographic Information and Geovisualization 45(3): 185-199.

Zackariasson, P., Styhre, A. and Wilson, T.L. (2006) Phronesis and Creativity: Knowledge Work in Video Game Development. Creativity and Innovation Management 15(4): 419-429. 